\title{
Hydrogen Peroxide Prompted Lignification Affects Pathogenicity of Hemi-bio- trophic Pathogen Bipolaris sorokiniana to Wheat
}

\author{
Ajit Poudel ${ }^{1}$, Sudhir Navathe $\mathbb{D}^{10}{ }^{1,5}$, Ramesh Chand ${ }^{10}{ }^{1 *}$, Vinod K. Mishra ${ }^{1}$, Pawan K. Singh ${ }^{2}$, and \\ Arun K. Joshi ${ }^{3,4}$ \\ ${ }^{1}$ Institute of Agricultural Sciences, Banaras Hindu University Varanasi- 221005 UP, India \\ ${ }^{2}$ International Maize and Wheat Improvement Center (CIMMYT), Apdo Postal 6-641, Mexico DF Mexico \\ ${ }^{3}$ Borlaug Institute for South Asia (BISA), G-2, B-Block, NASC Complex, DPS Marg, New Delhi-110012 India \\ ${ }^{4}$ International Maize and Wheat Improvement Center (CIMMYT), G-2, B-Block, NASC Complex, DPS Marg, New Delhi \\ - 110012 India \\ ${ }^{5}$ Current Address: Agharkar Research Institute, G.G. Agarkar Road, Pune-411004, India
}

(Received on September 7, 2018; Revised on April 9, 2019; Accepted on April 22, 2019)

Spot blotch caused by Bipolaris sorokiniana has spread to more than 9 million ha of wheat in the warm, humid areas of the Eastern Gangetic Plains (EGP) of South Asia and is a disease of major concern in other similar wheat growing regions worldwide. Differential lignin content in resistant and susceptible genotypes and its association with free radicals such as hydrogen peroxide $\left(\mathrm{H}_{2} \mathrm{O}_{2}\right)$, superoxide $\left(\mathrm{O}_{2}^{-}\right)$and hydroxyl radical $\left(\mathrm{OH}^{-}\right)$ were studied after inoculation under field conditions for two consecutive years. $\mathrm{H}_{2} \mathrm{O}_{2}$ significantly influenced lignin content in flag leaves, whereas there was a negative correlation among lignin and $\mathrm{H}_{2} \mathrm{O}_{2}$ to the Area Under Disease Progress Curve (AUDPC). The production of $\mathrm{H}_{2} \mathrm{O}_{2}$ was higher in the resistant genotypes than susceptible ones. The $\mathrm{O}_{2}^{-}$and $\mathrm{OH}^{-}$positively correlated with AUDPC but negatively with lignin content. This study illustrates that $\mathrm{H}_{2} \mathrm{O}_{2}$ has a vital role in prompting lignification and thereby resistance to spot blotch in wheat.

\footnotetext{
*Corresponding author.

Phone) +91-9415992810

E-mail)rc vns@yahoo.co.in

ORCID

Sudhir Navathe

https://orcid.org/0000-0002-8040-5563

Ramesh Chand

https://orcid.org/0000-0001-5231-224X

(c) This is an Open Access article distributed under the terms of the Creative Commons Attribution Non-Commercial License (http:// creativecommons.org/licenses/by-nc/4.0) which permits unrestricted noncommercial use, distribution, and reproduction in any medium, provided the original work is properly cited.
}

Articles can be freely viewed online at www.ppjonline.org.
We used cluster analysis to separate the resistant and susceptible genotypes by phenotypic and biochemical traits. $\mathrm{H}_{2} \mathrm{O}_{2}$ associated lignin production significantly reduced the number of appressoria and penetration pegs. We visualized the effect of lignin in disease resistance using differential histochemical staining of tissue from resistant and susceptible genotypes, which shows the variable accumulation of hydrogen peroxide and lignin around penetration sites.

Keywords : lignin, reactive oxygen species, resistance, spot blotch

Handling Editor : Sohn, Kee Hoon

Wheat is the first among the world's three most important staple crops - rice, wheat, and maize - being grown on over 215 million ha annually with a harvest of around 727.9 million tons and contributing nearly US $\$ 50$ billion (FAO 2018/19) each year to global markets. Wheat crops are exposed to various biotic and abiotic stresses and their survival depends on proper management and/or genetic defense mechanisms against these stresses. Spot blotch disease of wheat is caused by Cochliobolus sativus. Drechsler ex Dastur (anamorph Bipolaris sorokiniana (Sacc.) Shoem.), a hemibiotrophic fungus, and constitutes a significant constraint of the crop in warm, humid, tropical areas of Bangladesh, Bolivia, Brazil, India, Nepal, and Paraguay (Gupta et al., 2018; Gurung et al., 2013; Singh et al., 2015). Spot blotch of wheat has been documented as causing yield losses ranging between 16 to $20 \%$ annually (Dubin and van 
Ginkel, 1991) and as high as $100 \%$ in severe epidemics (Mehta, 1998). Resistance to spot blotch is quantitative and involves three genes $(S b 1, S b 2, S b 3)$ working in an additive manner (Gupta et al., 2018; Joshi et al., 2004). This type of spot blotch resistance slows the progress of the disease as a cumulative effect of the resistance genes (Eisa et al., 2013), but little has been known regarding the biochemical components involved (Yusuf et al., 2016).

Among the structural and biochemical resistance factors, lignin is the most important (Boudet, 2000) and lignification in cells plays a crucial role through programmed deposition around the pathogen penetration sites by creating a ring of lignified cells (Caño-Delgado et al., 2003; Tronchet et al., 2010). Being a primary defense molecules in plants against pathogens (Nicholson and Hammerschmidt, 1992), lignin makes the cell more rigid, resulting in resistant to mechanical pressure and chemical reaction applied by fungal pathogen during penetration (Bird and Ride 1981; Southerton and Deverall, 1990). These lignin depositions in wheat are not readily soluble and hence not digestible, thus creating a physical barrier against several pathogens (Bishop et al., 2002; Tronchet et al., 2010). Earlier studies also found that lignification around the infection site restricted the movement of water and nutrients to the fungus, retarding its growth (Elad and Evensen, 1995). Wheat cells use reactive oxygen species (ROS) as signal molecules that activate the primary and secondary metabolic pathways for lignin formation (Jacobo-Velázquez et al., 2015).

Various studies have reported the role of lignin in hostpathogen interactions (Bhuiyan et al., 2009; Bird and Ride, 1981; Miedes et al., 2014; Tronch et al., 2010), but few exist concerning the role of lignin on pathogen fitness. For this study we hypothesized that lignin affects pathogen fitness parameters such as latent period, lesion expansion and spore production, thereby slowing disease progress, and we looked infection-induced lignin production and its effect on pathogen fitness in association with free radicals produced during infection, with the ultimate aim of using this information to help characterize resistant genotypes.

\section{Materials and Methods}

Experimental design and wheat genotypes. The experiment was conducted using 29 bread wheat (Triticum aestivum L.) breeding lines (Table 1) developed by the International Maize and Wheat Improvement Center (CIMMYT) and selected from an original population of 968 genotypes known for resistance to spot blotch. To reduce confounding effects from differing plant height and days to maturity
(Joshi et al., 2002), we chose lines with a maturity range of 6 days to heading and with a plant height range of 100-120 $\mathrm{cm}$. The lines were sown in the second week of December to match the post-anthesis stages with warm temperatures during early February to early March, which are favorable for spot blotch (Joshi and Chand, 2002).

The experiment was carried out at the Agricultural Research Farm, Institute of Agricultural Sciences, Banaras Hindu University, Varanasi, India (NEPZ, $25.2^{\circ} \mathrm{N}$, and 83. $0^{\circ} \mathrm{E}$ ) over two seasons, $2014-15$ and $2015-16$ on a field that had been used for rice-wheat cropping during the previous 10 years. Crop management comprised $120 \mathrm{~kg} \mathrm{~N}$ : 60 $\mathrm{kg} \mathrm{P}_{2} \mathrm{O}_{5}: 40 \mathrm{~kg} \mathrm{~K}_{2} \mathrm{O}$ per ha fertilization, using a full dose of $\mathrm{P}_{2} \mathrm{O}_{5}$ and $\mathrm{K}_{2} \mathrm{O}$ at sowing but Nitrogen as split, $1 / 2$ at sowing and $1 / 4$ after first (21 days) and second (40 days) irrigations, with a total of 5 irrigations.

We used a randomized block design with 2 rows of 1 $\mathrm{m}$ each for each genotype sown with a $25 \mathrm{~cm}$ spacing between rows and 15 plants per row.

Inoculation and disease assessment. Spores of the $B$. sorokiniana strain HD 3069 (MCC 1572) were produced by aseptic culturing on sorghum grain (Chand et al., 2013). The spore suspension of $10^{4}$ spores $/ \mathrm{ml}$ of sterile water aided with $100 \mu$ Tween 20 was sprayed uniformly during evening hours at the half panicle emergence stage (ZGS 55, Zadoks et al., 1974) followed by light irrigation to maintain high humidity and night dew deposition for pathogenesis and disease development.

Ten plants of each line were randomly selected and tagged and disease progress (area under the disease progress curve, incubation period, latent period, lesion number, lesion size, spores $/ \mathrm{cm}^{2}$ lesion) was recorded on the tagged plants.

To measure pathogen fitness, incubation period was recorded upon observing the first visual symptom of disease on more than $50 \%$ plants (Parlevliet, 1979), and data related to latent period was collected and computed according to Das et al. (1993):

Latent period $=t_{1}+\left[\left(F / 2-n t_{1}\right)\left(t_{2}-t_{1}\right) /\left(n t_{2}-n t_{1}\right)\right]$

Where $\mathrm{F}=$ final number of lesions, $\mathrm{t}_{1}=$ day before $50 \%$ lesions sporulated, $\mathrm{t}_{2}=$ day after $50 \%$ lesions sporulated, $\mathrm{nt}_{1}=$ number of lesions sporulated at $\mathrm{t}_{1}, \mathrm{nt}_{2}=$ number of lesions sporulated at $\mathrm{t}_{2}$.

The relative rate of resistance for the latent period, sporulation, AUDPC, and fitness index of the pathogen was calculated according to Willocquet et al. (2017):

Relative rate resistance for latent period $(\mathrm{RRLP})=1-$ 
Table 1. Pedigree and spot blotch response of 29 wheat genotypes used in the experiment

\begin{tabular}{|c|c|c|c|c|c|c|c|}
\hline No. & Pedigree & $\begin{array}{l}\text { Reac- } \\
\text { tion }\end{array}$ & $\begin{array}{l}\text { Days to } \\
\text { heading } \\
\text { (days) }\end{array}$ & $\begin{array}{l}\text { Maturity } \\
\text { duration } \\
\text { (days) }\end{array}$ & $\begin{array}{l}\text { Biomass } \\
\quad(\mathrm{g})\end{array}$ & $\begin{array}{l}\text { TKW } \\
(\mathrm{g})\end{array}$ & $\begin{array}{l}\text { Plot } \\
\text { Yield } \\
(\mathrm{g})\end{array}$ \\
\hline 1 & CROC_1/AE.SQUARROSA (205)//KAUZ/3/ENEIDA & $\mathrm{R}$ & 81.17 & 105.5 & 313.72 & 35.51 & 110 \\
\hline 2 & ASTREB/OAX93.10.1//SOKOLL & $\mathrm{R}$ & 78.17 & 104.5 & 277.54 & 31.81 & 68.07 \\
\hline 3 & SURUTU-CIAT & $\mathrm{R}$ & 80.33 & 108.83 & 267.68 & 34.22 & 115.65 \\
\hline 4 & $\begin{array}{l}\text { CNDO/R143//ENTE/MEXI_2/3/AEGILOPS SQUARROSA (TAUS)/4/ } \\
\text { WEAVER/5/PASTOR }\end{array}$ & $\mathrm{R}$ & 75.5 & 108.17 & 211.22 & 30.3 & 101.31 \\
\hline 5 & $\begin{array}{l}\text { MILAN/KAUZ/3/URES/JUN//KAUZ/4/CROC_1/AE.SQUARROSA } \\
\text { (224)//OPATA }\end{array}$ & $\mathrm{R}$ & 82.67 & 104.83 & 276.69 & 32.47 & 93.01 \\
\hline 6 & TILHI/SOKOLL & $\mathrm{R}$ & 78.5 & 103.17 & 258.19 & 30.58 & 83.22 \\
\hline 7 & $\begin{array}{l}\text { UP2338*2/4/SNI/TRAP\#1/3/KAUZ*2/TRAP//KAUZ/5/MILAN/ } \\
\text { KAUZ//CHIL/CHUM18/6/UP2338*2/4/SNI/TRAP\#1/3/KAUZ*2/ } \\
\text { TRAP//KAUZ }\end{array}$ & $\mathrm{R}$ & 79 & 105.17 & 294.6 & 36.15 & 148.9 \\
\hline 8 & TILILA/TUKURU/4/SERI.1B*2/3/KAUZ*2/BOW//KAUZ & $\mathbf{S}$ & 79.5 & 102.5 & 263.93 & 31.99 & 89.05 \\
\hline 9 & PBW 343/PASTOR & $\mathrm{R}$ & 81 & 111.5 & 288.46 & 30.44 & 114.96 \\
\hline 10 & TILHI & $\mathrm{R}$ & 82.17 & 117 & 280.64 & 31.47 & 111.81 \\
\hline 11 & NL 750 & $\mathrm{R}$ & 80.83 & 117.5 & 270.21 & 32.11 & 105.73 \\
\hline 12 & ATTILA/3*BCN//BAV92/3/TILHI & $\mathrm{R}$ & 80 & 115.17 & 255.74 & 30 & 92.56 \\
\hline 13 & $\begin{array}{l}\text { ALTAR 84/AE.SQUARROSA (219)//OPATA/3/WBLL1/FRET2// } \\
\text { PASTOR }\end{array}$ & $\mathrm{R}$ & 78.33 & 116 & 240.31 & 32.33 & 81.53 \\
\hline 14 & CIANO T 79 & $\mathbf{S}$ & 79.83 & 101.33 & 197.73 & 22.66 & 54.17 \\
\hline 15 & ATTILA/3*BCN//BAV92/3/TILHI/4/SHA7/VEE\#5//ARIV92 & $\mathrm{R}$ & 80.17 & 117.5 & 290.49 & 29.42 & 77.51 \\
\hline 16 & $\begin{array}{l}\text { VORB/4/D67.2/PARANA 66.270//AE.SQUARROSA (320)/3/ } \\
\text { CUNNINGHAM }\end{array}$ & $\mathrm{R}$ & 80.33 & 115.67 & 282.85 & 36.51 & 127.29 \\
\hline 17 & CMH79A.955/4/AGA/3/4*SN64/CNO67//INIA66/5/NAC/6/RIALTO & $\mathrm{R}$ & 80.5 & 114 & 274.02 & 34.52 & 124.96 \\
\hline 18 & MEX94.2.19 & $\mathbf{S}$ & 79.5 & 97 & 214.93 & 22.75 & 62.87 \\
\hline 19 & PBW343*2/KUKUNA//PBW343*2/TUKURU/3/PBW343 & $\mathrm{R}$ & 79.83 & 106.67 & 305.45 & 34.63 & 106.57 \\
\hline 20 & YANGMAI-6 & $\mathrm{R}$ & 81.5 & 115 & 263.01 & 36.5 & 78.5 \\
\hline 21 & PBW343*2/KUKUNA//TECUE \#1 & $\mathrm{R}$ & 84.67 & 107.17 & 249.93 & 32.64 & 114.87 \\
\hline 22 & UP2338*2/KKTS*2//YANAC & $\mathrm{R}$ & 79.5 & 108.5 & 246.69 & 31.65 & 128.31 \\
\hline 23 & MURGA/KRONSTAD F2004 & $\mathrm{R}$ & 77.33 & 104.17 & 262.38 & 31.49 & 113.4 \\
\hline 24 & SAUAL/KIRITATI//SAUAL & $\mathrm{R}$ & 83.33 & 112 & 236.05 & 31.97 & 118.36 \\
\hline 25 & BABAX/LR39//BABAX/3/VORB/4/SUNCO/2*PASTOR & $\mathrm{R}$ & 82.33 & 107.83 & 310.42 & 30.44 & 115.58 \\
\hline 26 & $\begin{array}{l}\text { WBLL1*2/KURUKU*2/5/REH/HARE//2*BCN/3/CROC_1/ } \\
\text { AE.SQUARROSA (213)//PGO/4/HUITES }\end{array}$ & $\mathbf{S}$ & 78.5 & 101 & 251.74 & 30.02 & 81.29 \\
\hline 27 & $\begin{array}{l}\text { KACHU \#1/4/CROC_1/AE.SQUARROSA (205)//KAUZ/3/SASIA/5/ } \\
\text { KACHU }\end{array}$ & $\mathrm{R}$ & 80.67 & 112.17 & 302.54 & 35.71 & 86.69 \\
\hline 28 & OPATA//SORA/AE.SQUARROSA (323) & $\mathrm{R}$ & 80.83 & 109.5 & 297.52 & 37.33 & 149.4 \\
\hline \multirow[t]{2}{*}{29} & WBLL1*2/KUKUNA//AKURI \#1 & $\mathbf{S}$ & 76.5 & 99.33 & 225.44 & 27.29 & 109.91 \\
\hline & $\operatorname{MSD}(0.05)$ & & 3.53 & 4.91 & 58.65 & 5.54 & 32.45 \\
\hline
\end{tabular}

AUDPC: Area Under Disease Progress Curve; TKW: Thousand kernel weight R: Resistant; S: Susceptible

\section{(LPS/LPX)}

Where LPS and LPX are the latent periods for the genotype

The same formula was used to calculate the relative rate of resistance to spore production, fitness index, and AUDPC, where LPS and LPX are the latent periods measured for the genotype to be characterized by susceptible control genotype CIANO T79.

To measure lesion size and number of lesions $/ \mathrm{cm}^{2}, 10$ flag leaves per replication of tagged plants in each row were photographed using a Nikon D5200 (Nikon, Tokyo, Japan) digital camera and the images were examined in 
Adobe Photoshop using an analysis plug in to quantify lesion sizes and numbers on individual leaves.

The disease was scored visually when all lines showed symptoms. AUDPC was calculated based on disease severity at GS63, GS69, and GS77 as outlined by Shaner and Finney (1977):

$$
\text { AUDPC }=\sum_{i=1}^{n}\left(\frac{Y_{\mathrm{i}}+\mathrm{Y}_{\mathrm{i}+1}}{2}\right)\left(\mathrm{t}_{\mathrm{i}+1}-\mathrm{t}_{\mathrm{i}}\right)
$$

Where $y_{i}$ is an assessment of disease at the ith observation, $t_{i}$ is time (in days) at the ith observation, and $n$ is the total number of observations.

\section{Assessment of lignin and reactive oxygen species}

Raising of lines and sampling. All 29 genotypes evaluated under field conditions were planted in pots under a poly-house and inoculated using a mono-conidial isolate of B. sorokiniana strain HD 3069 (MCC 1572). We maintained a temperature of $24 \pm 2^{\circ} \mathrm{C}$ and a relative humidity $\geq 80 \%$ using fogging. Flag leaves were collected before and after inoculation of the pathogen at four different times $(0,3,7$ and $14 \mathrm{DAI})$ from tagged plants. For ROS, flag leaves were excised, immediately cooled in liquid nitrogen and stored at $-80^{\circ} \mathrm{C}$ for further assays. For lignin estimation two flag leaves/genotypes were collected in paper envelops and were oven dried for overnight at $60^{\circ} \mathrm{C}$.

Assay of reactive oxygen species and lignin. $\mathrm{H}_{2} \mathrm{O}_{2}$ was estimated according to Patterson et al. (1984). Leaf samples (200 mg) were homogenized in a sodium-phosphate buffer $(5 \mathrm{mM}, \mathrm{pH} 6.5)$ and the extract centrifuged at $10,000 \times$ $g$ for $15 \mathrm{~min}$. The reaction was initiated by adding $\mathrm{TiSO}_{4}$ (HiMedia, India GRM2484) $\left(1 \%\right.$ in $\left.20 \% \mathrm{H}_{2} \mathrm{SO}_{4}\right)$ to the supernatant. The reaction mixture was again centrifuged at $10,000 \times \mathrm{g}$ for $15 \mathrm{~min}$ and absorbance recorded at $\lambda 410$ $\mathrm{nm}$ on Double Beam UV-VIS Spectrophotometers (ELICO, Hyderabad, India SL196). The quantity of $\mathrm{H}_{2} \mathrm{O}_{2}$ was expressed as $\mu \mathrm{M}$ per gram fresh weight using an extinction coefficient of 53.5714 .

Superoxide radicals $\left(\mathrm{O}_{2}^{-}\right)$were estimated according to Misra and Fridovich (1972). The reaction mixture contained $20 \mu \mathrm{M}$ of sodium-phosphate buffer (pH 7), $20 \mu \mathrm{M}$ NADH (AMRESCO, India, Product code: 0384), $100 \mu \mathrm{M}$ disodium EDTA and $1.2 \mathrm{mM}$ epinephrine (Sigma, Missouri, US E4642). Change in the absorbance was noted at $\lambda 480 \mathrm{~nm}$ for $10 \mathrm{~min}$.

The protocol of Halliwell et al. (1987) was used to measure hydroxyl radicals $\left(\mathrm{OH}^{-}\right) .100 \mathrm{mg}$ of fresh leaf sample was homogenized into $2 \mathrm{ml}$ of $50 \mathrm{mM}$ sodium- phosphate buffer ( $\mathrm{pH} 7$ ) and centrifuged at 22,000 $\times g$ for 15 minutes at $4{ }^{\circ} \mathrm{C}$. The reaction mixture contained $1 \mathrm{ml}$ of supernatant, $0.8 \mathrm{ml}$ of $2.5 \mathrm{mM}$ 2-deoxyribose and $200 \mu \mathrm{l}$ of $2 \mathrm{mM}$ $\mathrm{FeSO}_{4}$ incubated in the dark for one hour. TBA $(0.25 \%$ in $10 \%$ of TCA) was added, reaction mixture boiled at $80^{\circ} \mathrm{C}$ for 20 minutes and immediately cooled. The whole reaction mixture was then centrifuged at $3,000 \times \mathrm{g}$ for $10 \mathrm{~min}$, and absorbance noted at $\lambda 352 \mathrm{~nm}$.

Lignin was quantified as per Aldaeus (2011). A $100 \mathrm{mg}$ oven-dried sample was digested in $75 \%$ sulphuric acid by incubation in a water bath at $35^{\circ} \mathrm{C}$ for $1 \mathrm{~h}$, followed by autoclaving at $121^{\circ} \mathrm{C}$ for $1 \mathrm{~h}$. The solution was filtered through pre-weighed Whatman's filter paper (Grade 01). The filtrate was used to measure soluble acid lignin (ALS), and residue over filter paper was used for quantification of insoluble acid residue.

The total lignin was calculated by following formulae:

a) Acid-insoluble residue $(\mathrm{AIR})=(\mathrm{m} / \mathrm{M}) \times 1,000 \mathrm{mg} / \mathrm{g}$,

b) Acid soluble lignin $(\mathrm{ASl})=((\mathrm{A} . \mathrm{D} . \mathrm{V}) /($ a.b.M $)) \times 1,000$ $\mathrm{mg} / \mathrm{g}$,

c) Total lignin content $=$ AIR + ASL

Where $\mathrm{m}=$ the residue after drying in $\mathrm{g}, \mathrm{M}=$ Oven-dry weight of sample before acid hydrolysis/suspension, in $\mathrm{g}$, $\mathrm{A}=$ Absorption at $205 \mathrm{~nm}, \mathrm{D}=$ Dilution factor, $\mathrm{V}=$ Volume of the filtrate, in $1, a=$ Extinction coefficient of lignin, in $\mathrm{g} / \mathrm{l} \mathrm{cm}$ (here: $110 \mathrm{~g} / \mathrm{l} \mathrm{cm}$, according to TAPPI UM 250), $\mathrm{b}=$ cuvette path length, in $\mathrm{cm}$ (here: $1 \mathrm{~cm}$ ), $\mathrm{M}=$ Weight of sample (as $100 \%$ dry matter) before acid hydrolysis/suspension, in $\mathrm{g}$

Histo-pathological assay and histochemical staining. Staining for lignin deposition was done using a phloroglucinol-HCl (Wiesner) test (Beardmore et al., 1983). Flag leaves were taken from tagged plants. Infected leaves and disease free leaf segments were soaked in a $10 \% \mathrm{w} / \mathrm{v}$ phloroglucinol solution in $95 \%$ ethanol for $3 \mathrm{~min}$, drained and placed in a drop of $10 \mathrm{M} \mathrm{HCl}$ on a slide, covered with a thin glass sheet, sealed with paraffin and observed for a purple-red vein as an indicator of lignin. The localization of $\mathrm{H}_{2} \mathrm{O}_{2}$ generation in leaf samples was done using 3, 3'-diaminobenzidine (DAB, Sigma, Missouri, US) staining (Thordal-Christensen et al., 1997). Three leaf segments of 1 $\mathrm{cm}^{2}$ from 5 tagged plants were collected and submerged in a solution containing $5 \mathrm{ml}$ of DAB stain $(1,000 \mu \mathrm{l} / \mathrm{ml})$. The tubes were placed on a standard laboratory electrical shaker for 7-8 $\mathrm{h}$ to allow the uptake of $\mathrm{DAB}$ and its reaction with $\mathrm{H}_{2} \mathrm{O}_{2}$ at $80-100 \mathrm{rpm}$. After leaves were stained, DAB was replaced by a bleaching solution (ethanol: acetic acid: glycerol $=3: 1: 1)$ and the tubes placed carefully in boiling water $\left(90-95^{\circ} \mathrm{C}\right)$ for $15 \mathrm{~min}$ to bleach out the chlorophyll. After 
15 min of boiling, the bleaching solution was replaced by a fresh bleaching solution and allowed to stand for $30 \mathrm{~min}$. $\mathrm{DAB}$ and lignin stained infected tissues were examined and photographed of using a Nikon Eclipse E200 microscope (Nikon, Tokyo, Japan). The development of appressoria and the colonization of host tissue by the pathogen were assessed by sampling inoculated leaves at 24, 48, 72, 96 hpi. The number of appressoria, number of penetrating pegs and distortion of appressoria if any were noted under the microscope, using the methodology of Sillero and Rubiales (2002).
Statistical analysis. Statistical analyses were performed using SAS (version 9.2; SAS Institute Cary, NC, USA). Data were first tested using the Shapiro and Wilkes (1965) test for normality and the homogeneity of variance among the groups determined by using the Levene test (Levene, 1960). Pooled data of two years were subjected for variance analysis in a general linear model using the PROC GLM procedure. Correlation, clustering, and principal component analysis were done using the PROC CORR, PROC CLUSTER and PROC VARCLUS procedures of SAS 9.2 (SAS Institute, Cary, NC). Bonferroni's adjust-
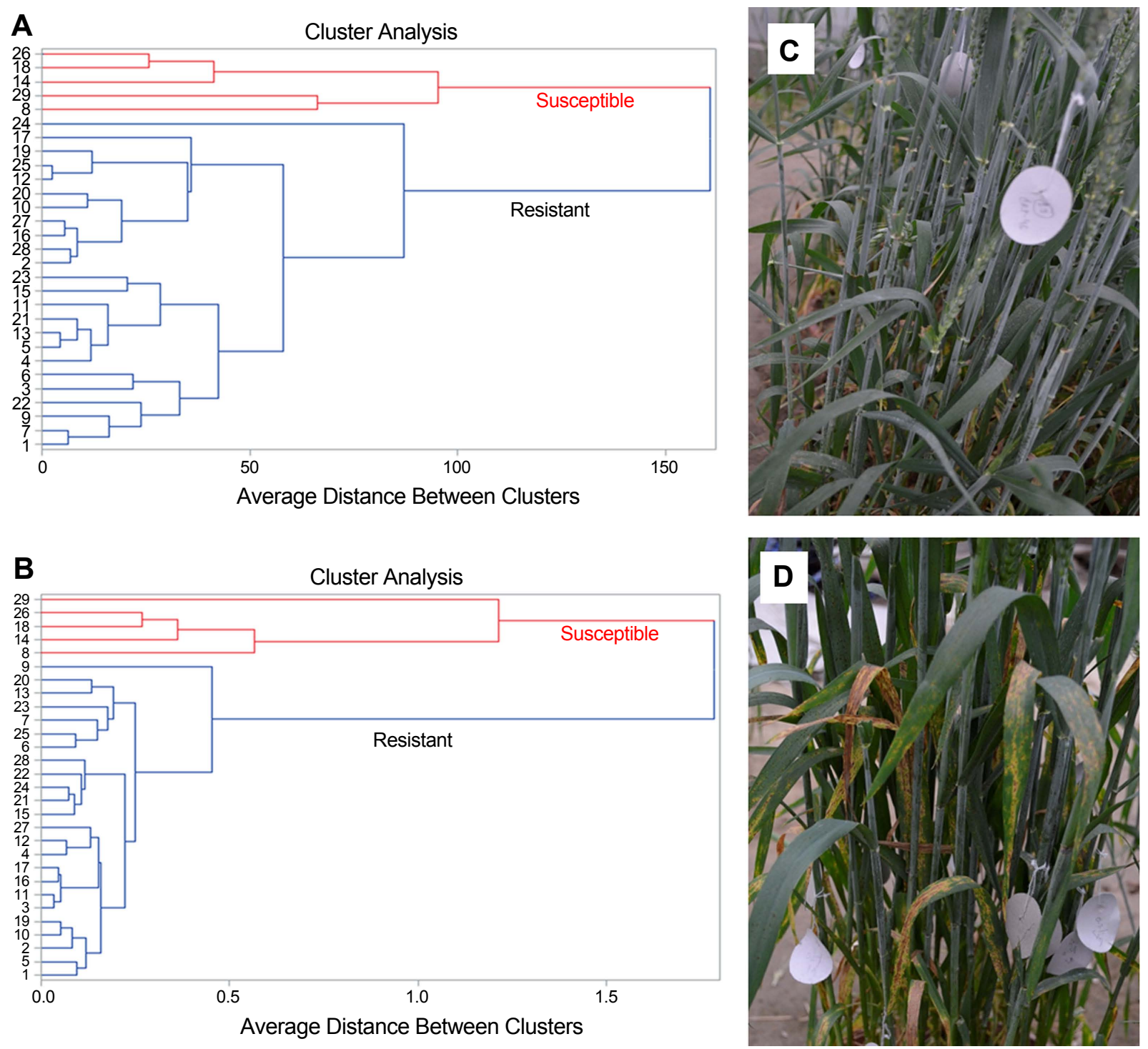

Fig. 1. Cluster analysis of 29 wheat genotypes on the basis their response to B. sorokiniana over two years in terms of (A) free radical production and lignin accumulation and, (B) various phenotypic traits such as AUDPC, LN, LS, DH, DM, PY, BM, and TKW. Clades highlighted with red lines are indicating clustering of susceptible genotypes whereas those of blue are resistant. (C) Plants from a resistant group; genotype Yangmai 6. (D) Plants showing typical symptoms of spot blotch seven days after inoculation on susceptible genotype Ciano T79. 


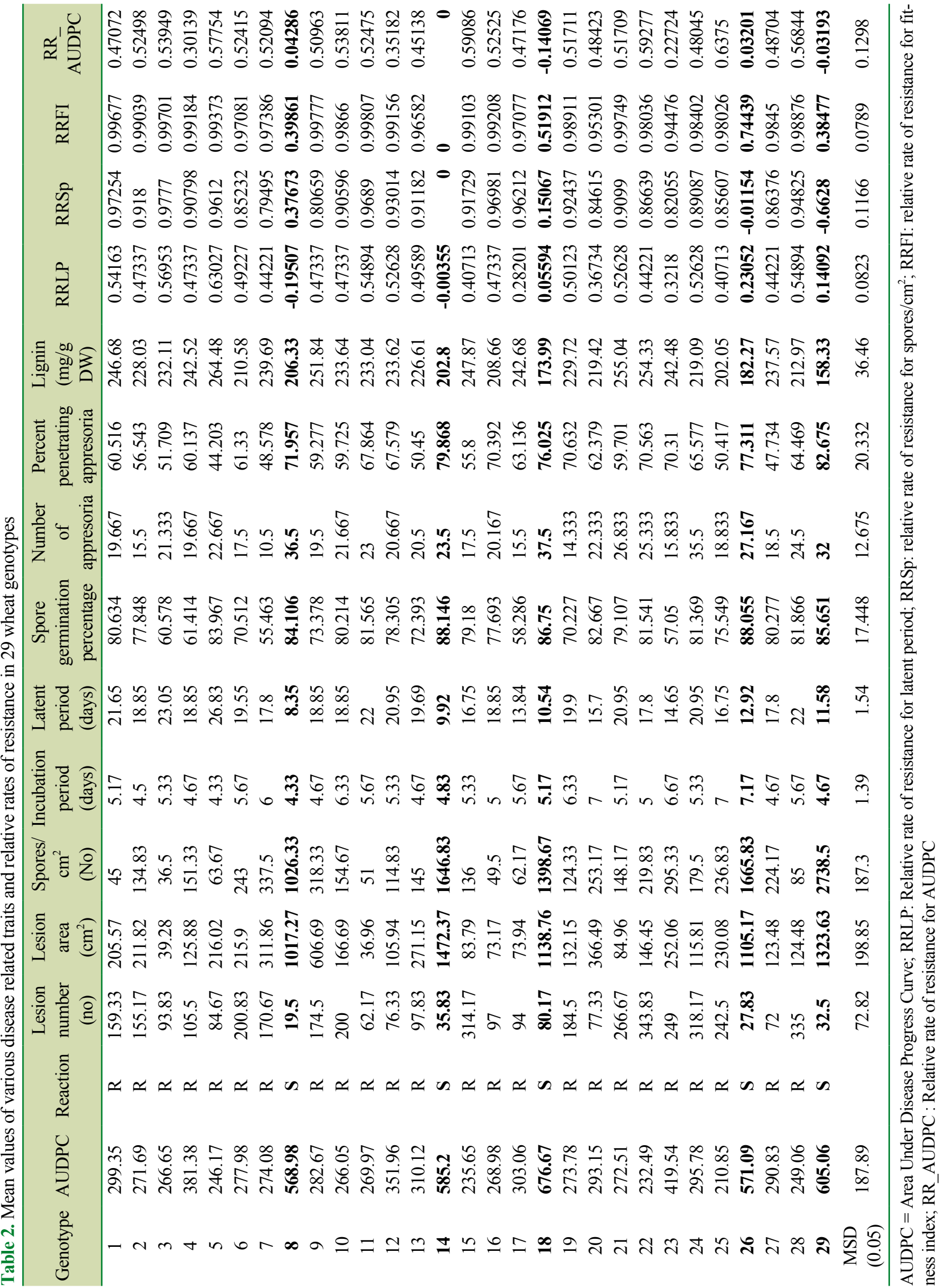


ments at $P=0.05$ were used to compare pairs of treatment means.

\section{Results}

Phenotypic variation and response of genotypes to $B$. sorokiniana. Cluster analysis of 29 genotypes based on 12 phenotypic parameters, lignin content and free radical production in response to $B$. sorokiniana infection separated them into two groups (Fig. 1A and B). Five susceptible genotypes $(8,14,18,26$ and 29) formed a single clade (Fig. 1A) while the remaining (20) resistant genotypes formed another clade (Fig. 1B) and clustered into the second group. The typical resistant and susceptible responses to $B$. sorokiniana are depicted in Fig. $1 \mathrm{C}$ and D. The combined ANOVA (Supplementary Table 1) indicated significant differences in phenotypic traits for the year, genotype and year $\times$ genotype.

The mean phenotypic character values for two independent experiments are presented in Table 2. In susceptible genotypes, AUDPC and other disease components such as lesion area, spores $/ \mathrm{cm}^{2}$, spore germination percentage, number of appressoria, percent penetrating appressoria were the highest, whereas yield components (biomass, plot yield, and thousand kernel weight) were lowest (Table 1).

The relative rate resistance for the latent period, sporulation, AUDPC, and fitness index of pathogen. The relative rate of resistance measures the ability of a genotype to counter pathogen infection cycles. In our study, the lignin accumulation directly affected the pathogen latent period and spore production, implying reduced fitness and slower

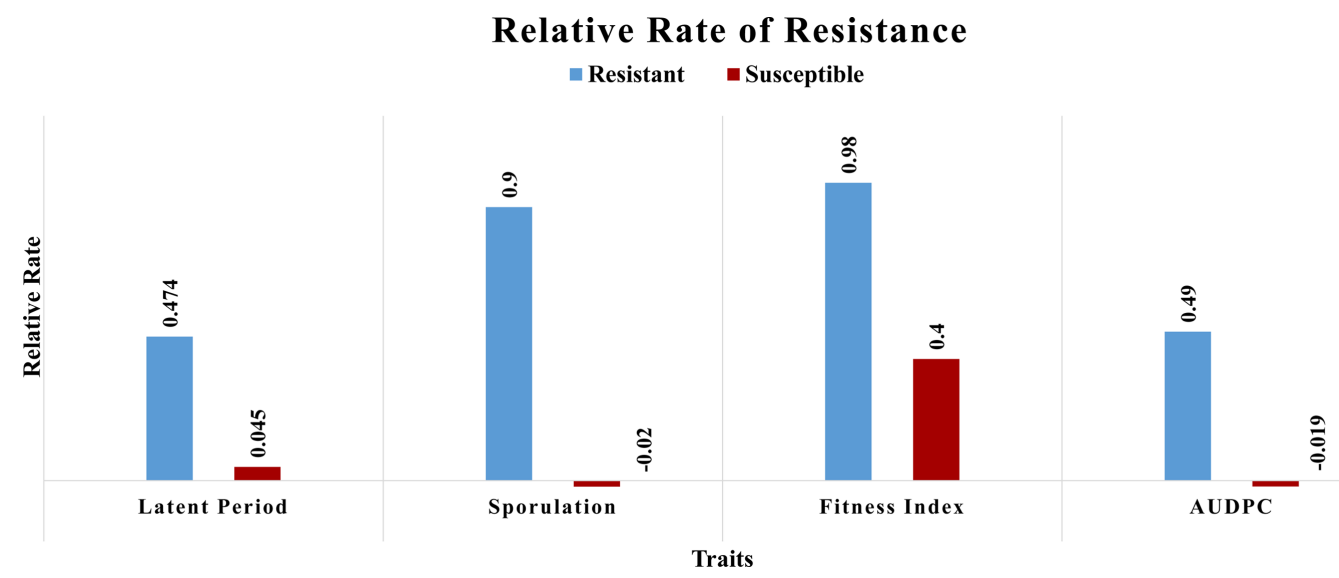

Fig. 2. Relative rates of resistance for the latent period, sporulation, fitness index, and AUDPC in resistant and susceptible genotypes. The relative rate of resistance in 29 wheat genotypes studied is calculated over the susceptible check Ciano T79.

Table 3. Pearson's correlation coefficients for disease, fitness parameters and relative rate of resistance for B. sorokiniana

\begin{tabular}{|c|c|c|c|c|c|c|c|c|c|c|c|}
\hline & AUDPC & $\begin{array}{l}\text { Lesion } \\
\text { number }\end{array}$ & $\begin{array}{c}\text { Lesion } \\
\text { area }\end{array}$ & Spore $/ \mathrm{cm}^{2}$ & $\begin{array}{c}\text { Incubation } \\
\text { period }\end{array}$ & $\begin{array}{l}\text { Latent } \\
\text { period }\end{array}$ & $\begin{array}{c}\text { Fitness } \\
\text { index }\end{array}$ & $\begin{array}{l}\text { Lignin } \\
\text { content }\end{array}$ & RRLP & RRSp & RRFI \\
\hline AUDPC & 1 & & & & & & & & & & \\
\hline Lesion Number & $-0.474 *$ & 1 & & & & & & & & & \\
\hline Lesion area & $0.719^{*}$ & $-0.454 *$ & 1 & & & & & & & & \\
\hline Spore $/ \mathrm{cm}^{2}$ & $0.761 *$ & $-0.430 *$ & $0.897 *$ & 1 & & & & & & & \\
\hline Incubation period & -0.073 & 0.126 & $-0.086^{*}$ & -0.059 & 1 & & & & & & \\
\hline Latent period & $-0.643^{*}$ & $0.359 *$ & $-0.705^{*}$ & $-0.691 *$ & -0.079 & 1 & & & & & \\
\hline Fitness index & 0.697 & $-0.450 *$ & $0.902 *$ & $0.821 *$ & -0.171 & $-0.718 *$ & 1 & & & & \\
\hline Lignin content & $-0.536^{*}$ & $0.321 *$ & $-0.590 *$ & $-0.661 *$ & -0.091 & $0.497 *$ & $-0.545^{*}$ & 1 & & & \\
\hline RRLP & $-0.764^{*}$ & $0.430^{*}$ & $-0.794 *$ & $-0.747^{*}$ & 0.054 & $0.910^{*}$ & $-0.838^{*}$ & $0.533^{*}$ & 1 & & \\
\hline RRSp & $-0.763^{*}$ & $0.432 *$ & $-0.897^{*}$ & $-0.999 *$ & 0.060 & $0.689 *$ & $-0.822 *$ & $0.663 *$ & $0.748 *$ & 1 & \\
\hline RRFI & $-0.696^{*}$ & $0.450 *$ & $-0.901 *$ & $-0.820 *$ & 0.169 & $0.720 *$ & $-0.999 *$ & $0.544 *$ & $0.839 *$ & $0.821 *$ & 1 \\
\hline
\end{tabular}

AUDPC = Area Under Disease Progress Curve; RRLP: Relative rate of resistance for latent period; RRSp: relative rate of resistance for spores/ $\mathrm{cm}^{2}$; RRFI: relative rate of resistance for fitness index; RR_AUDPC: Relative rate of resistance for AUDPC. ${ }^{*}$ Indicates positive correlation at $P$ $<0.0001$ 

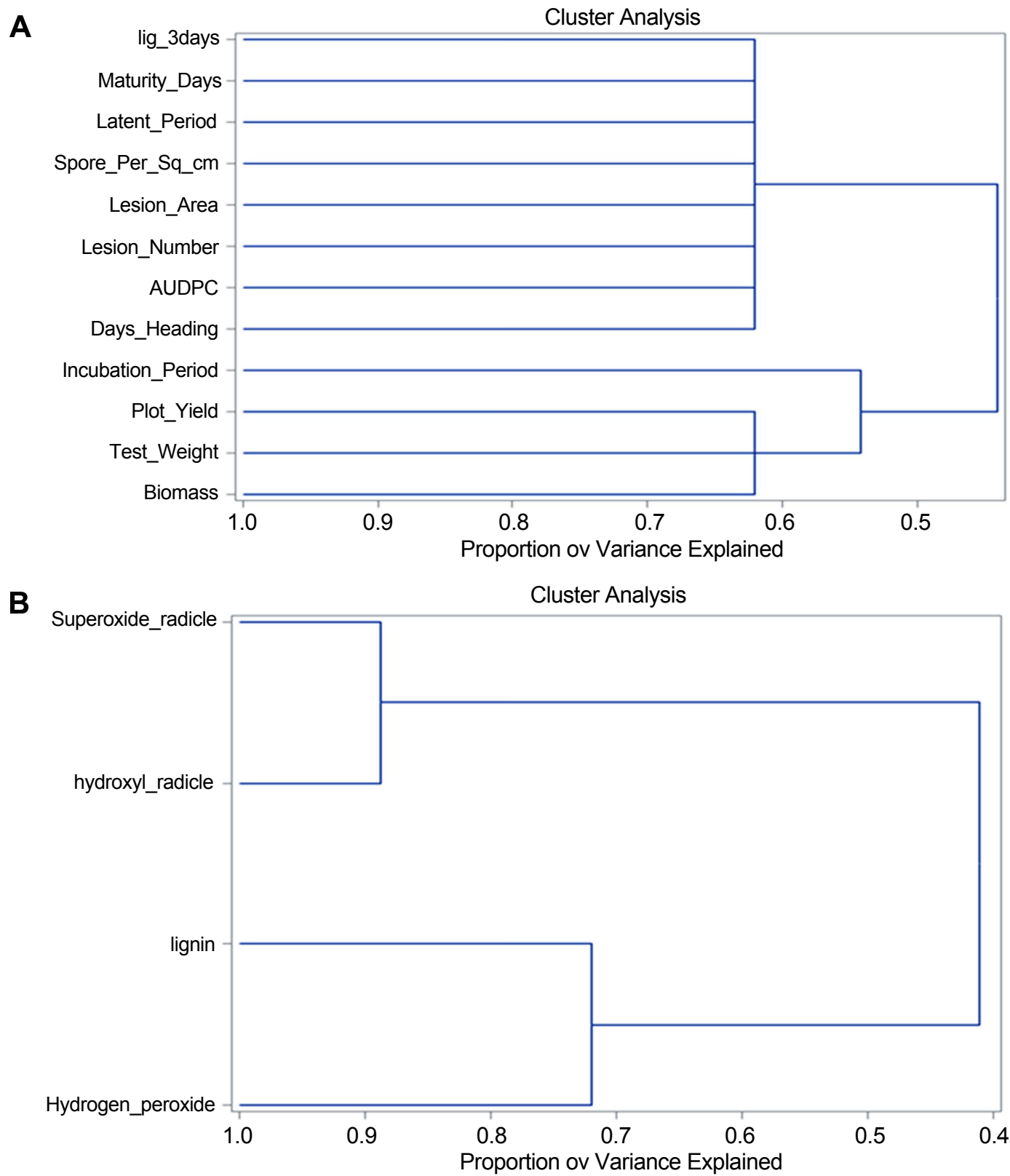

Fig. 3. Clustering of the correlated and non-correlated variables using the VARCLUS method in SAS v9.2 (A) Clustering of phenotypic traits and lignin content at three days. The components of the disease clustered together, indicating that enhanced resistance correlated to higher yield. (B) Clustering of biochemical traits indicating $\mathrm{H}_{2} \mathrm{O}_{2}$ is significantly affecting lignin production.

disease progress. The relative rate of resistance for sporulation, latent period, and AUDPC and the host fitness index were higher in resistant genotypes than susceptible ones. (Table 2, Fig. 2). These results were confirmed in the histopathological analysis, wherein ROS associated lignin production significantly reduced the number of aspersoria and of direct penetration pegs in resistant genotypes (Table 2).

Correlations between fitness parameters and disease associated traits. The estimates of linear correlation coef- ficients (Table 3) showed that AUDPC was positively and significantly correlated with lesion area and sporulating lesions whereas significantly and negatively correlated with lesion number, latent period, maturity duration, biomass, thousand kernel weight (TKW), plot yield, and lignin content. Lesion number was positively and significantly associated with the latent period and lignin content, but negatively with lesion area and sporulating lesions. These and other correlations appear in Table 3.

All traits separated into two clusters (Fig. 3A); cluster 1 

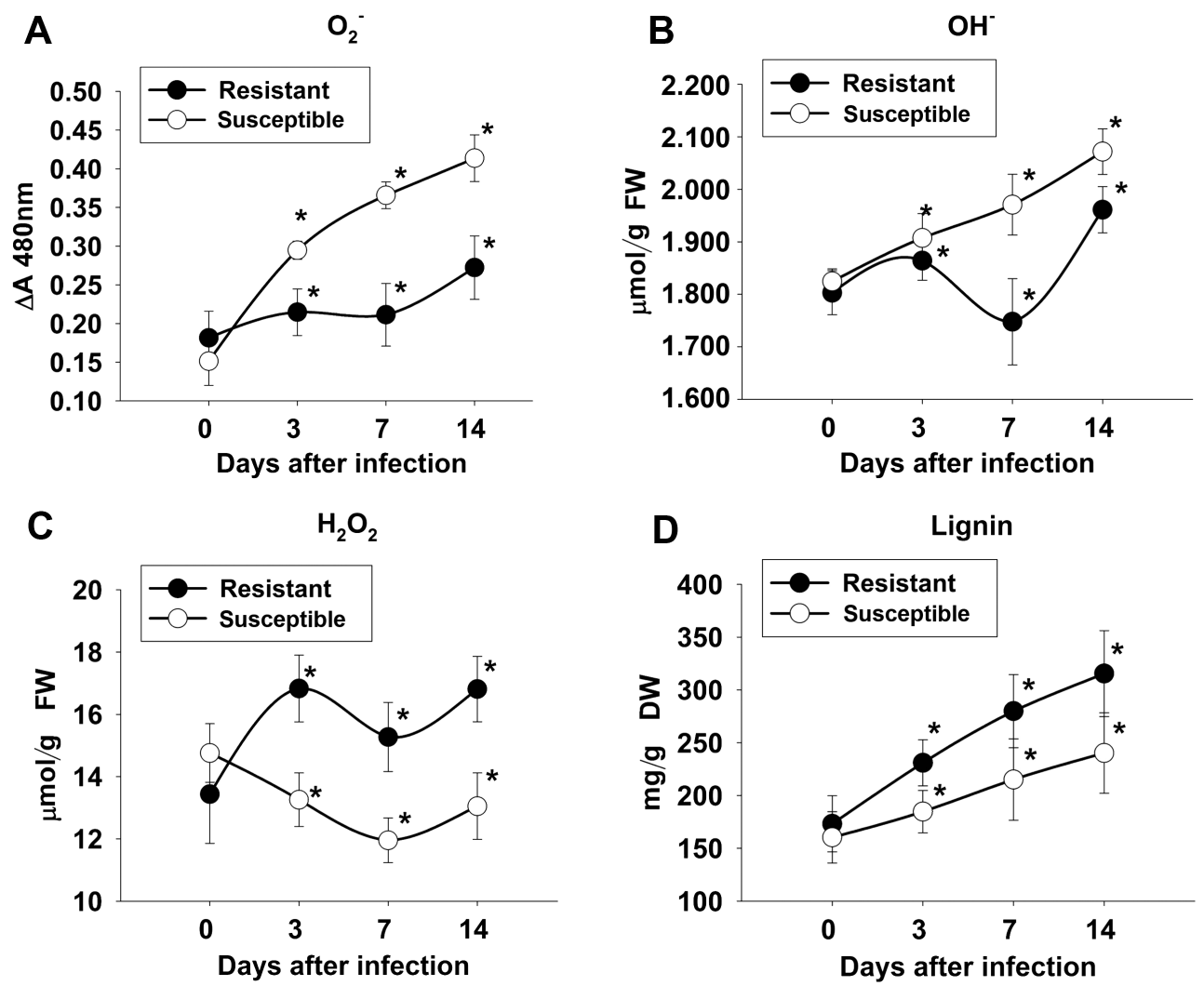

Fig. 4. Accumulation of various reactive oxygen species and lignin at different time points in resistant and susceptible wheat genotypes in response to $B$. sorokiniana infection. (A) Accumulation of superoxide radicals $\left(\mathrm{O}_{2}^{-}\right)$. The plot is based on mean $\mathrm{O}_{2}^{-}$accumulation in resistant and susceptible genotypes. LSD (0.05) for genotype $=0.0064$ and for time $=0.0024$. (B) Hydroxyl radical $\left(\mathrm{OH}^{-}\right)$production. The plot is based on mean $\mathrm{OH}^{-}$accumulation in resistant and susceptible genotypes. LSD (0.05) for genotype $=19.626$ and for time $=$ 7.2889. (C) Hydrogen peroxide $\left(\mathrm{H}_{2} \mathrm{O}_{2}\right)$ production. The plot is based on mean $\mathrm{H}_{2} \mathrm{O}_{2}$ accumulation in resistant and susceptible genotypes. LSD $(0.05)$ for genotype $=0.3143$ and for time $=0.1167$. (D) Lignin accumulation. The plot is based on mean $\mathrm{H}_{2} \mathrm{O}_{2}$ accumulation in resistant and susceptible genotypes. LSD (0.05) for genotype $=18.479$ and for time $=6.8629$. Data from two independent experiments are combined. ANOVA calculates the significant difference in the general linear model (GLM). Asterisks $(*)$ show the significant difference as compared to time $0 \mathrm{DAI}$.

includes AUDPC, days to heading, lesion area, lesion number, spores per $\mathrm{cm}^{2}$, latent period, maturity duration and lignin content that explains maximum variation (Supplementary Table 2). The yield components plot yield, test weight and biomass clustered in another separate cluster indicating the adverse effect of the disease on yield components.

Biochemical studies. The combined ANOVA (Supplementary Table 1) showed a significant difference for year, treatment, time and interaction for different biochemical components. We found significant variation for biochemical factors in wheat genotypes. The interactions year $x$ time, time $\times$ genotype year $\times$ genotype were also significant for all biochemical components and LIG. The interaction year $\times$ time $\times$ genotypes was significant only for $\mathrm{H}_{2} \mathrm{O}_{2}$, $\mathrm{OH}^{-}$, and $\mathrm{O}_{2}^{-}$.

The mean values of all the biochemical traits $\left(\mathrm{O}_{2}^{-}, \mathrm{OH}^{-}\right.$,
$\mathrm{H}_{2} \mathrm{O}_{2}$, and LIG) at different times for 29 wheat genotypes in response to flag leaf infection with $B$. sorokiniana are shown in Supplementary Table 4-7 and in Supplementary Fig. 1-4. Higher $\mathrm{O}_{2}^{-}$and $\mathrm{OH}^{-}$, lower $\mathrm{H}_{2} \mathrm{O}_{2}$ and LIG were observed in genotypes 8, 14, 18, 26 and 31; likewise, lower $\mathrm{O}_{2}{ }^{-}$and $\mathrm{OH}^{-}$, higher $\mathrm{H}_{2} \mathrm{O}_{2}$ and lignin appeared in the remaining lines. At 0 DAI (before inoculation), there was no significant difference in biochemical content between resistant and susceptible genotypes. The activity of $\mathrm{O}_{2}^{-}$(Fig. 4A) was elevated at $3 \mathrm{DAI}$ and continuously increased to 7 and 14 DAI in susceptible genotypes. In resistant genotypes, $\mathrm{O}_{2}^{-}$had increased slightly by 3 DAI and reached a maximum at 14 DAI. The continuous increase in $\mathrm{OH}^{-}$(Fig. 4B) was also observed in susceptible genotypes at all times but was elevated at $3 \mathrm{DAI}$, reduced at $7 \mathrm{DAI}$ and reached a maximum at $14 \mathrm{DAI}$, in resistant genotypes. Likewise, $\mathrm{H}_{2} \mathrm{O}_{2}$ increased at 3 DAI, decreased in 7 DAI, and became 
A
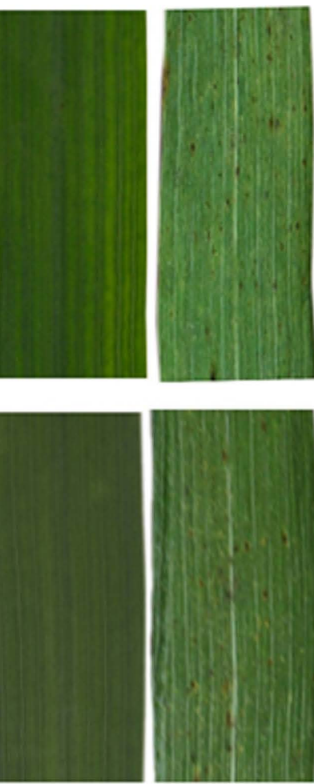

3 dai

C

$\mathbf{R}$

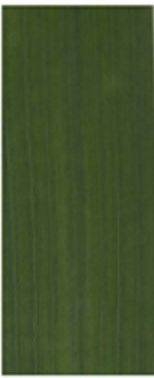

0 dai
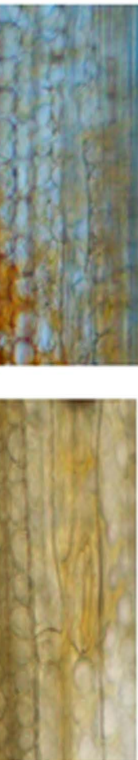

0 dai
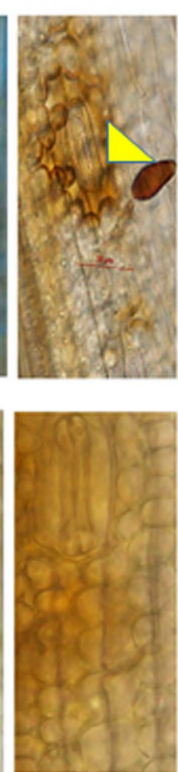

3 dai
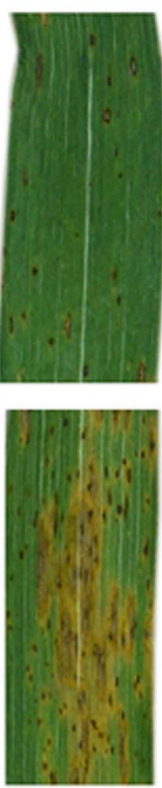

7 dai
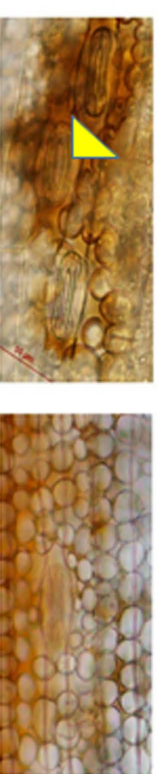

7 dai
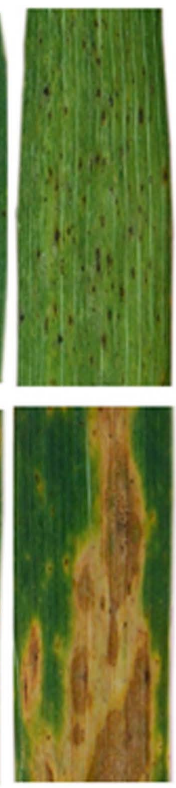

14 dai
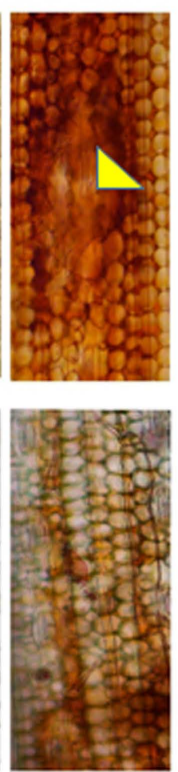

14 dai
B
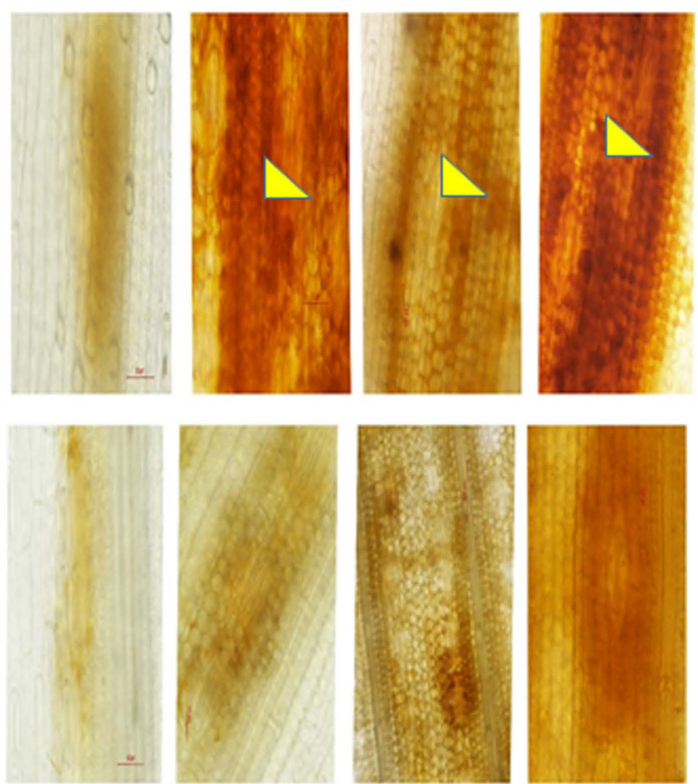

0 dai

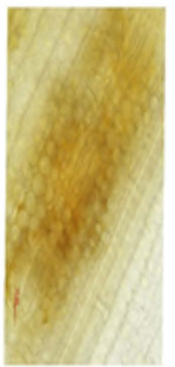

3 dai

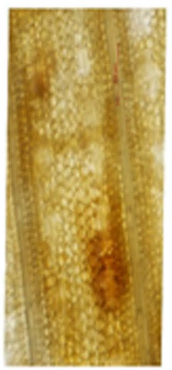

7 dai

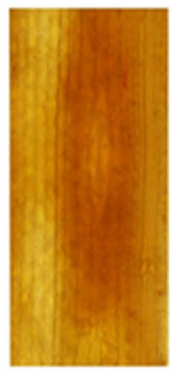

14 dai

D
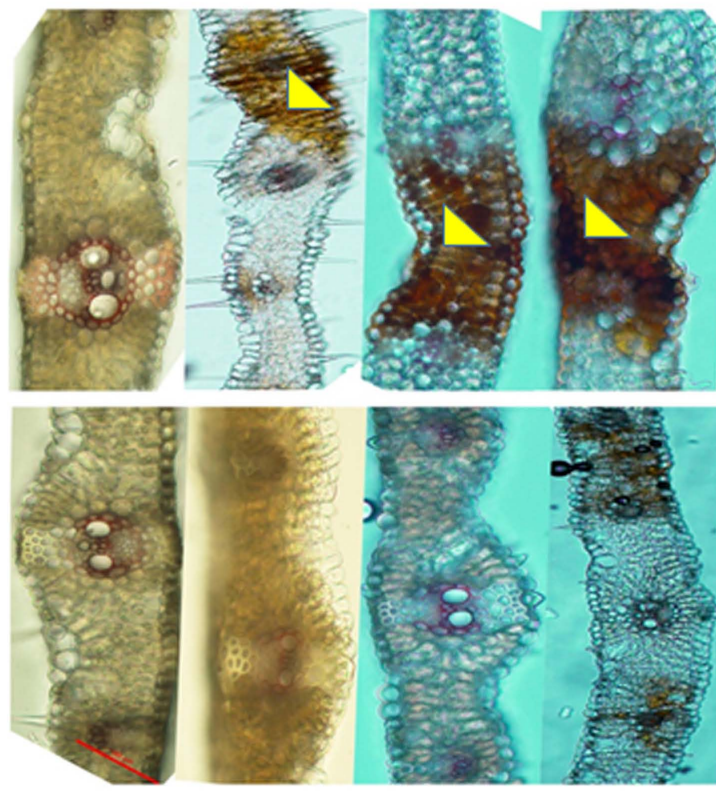

3 dai
7 dai

14 dai

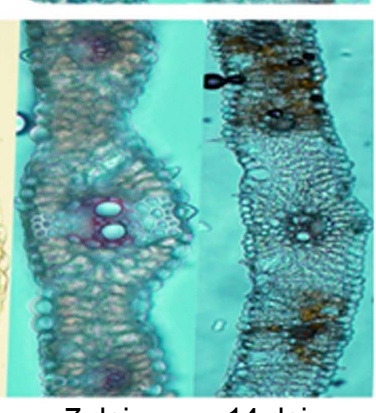

Fig. 5. (A) Symptoms of B. sorokiniana on flag leaves over time; (B) Differential accumulation of $\mathrm{H}_{2} \mathrm{O}_{2}$ in response to B. sorokiniana visualized by DAB staining in flag leaves under time scan 0 to 14 days after infection (DAI). (C) Lignin deposition in flag leaves in response to $B$. sorokiniana as visualized by phloroglucinol- $\mathrm{HCl}$ staining in a longitudinal section of leaves from 0 to $14 \mathrm{DAI}$. (D) Lignin deposition in flag leaves in response to $B$. sorokiniana as visualized by phloroglucinol-HCl staining in the transverse section of leaves from 0 to 14 DAI. The upper panel represents resistant (R) genotype (Cv. Yangmai6) and the lower panel the susceptible (S) genotype (Cv. Ciano T79). Penetration points are marked by yellow arrowheads. Red line shown in the picture indicates size bar.

elevated at 14 DAI in resistant genotypes (Fig. 4C). In susceptible genotypes, $\mathrm{H}_{2} \mathrm{O}_{2}$ continuously decreased up to 7 DAI and began increasing at 14 DAI. Lignin (Fig. 4D) continuously increased in both susceptible and resistant genotypes but fold change was significantly higher in resistant genotypes.

$\mathrm{DAB}$ and phloroglucinol- $\mathrm{HCl}$ staining of resistant and susceptible genotypes for $\mathrm{H}_{2} \mathrm{O}_{2}$ and lignin are shown in 
Table 4. Correlations among $\mathrm{H}_{2} \mathrm{O}_{2}, \mathrm{OH}^{-}, \mathrm{O}_{2}^{-}$, and lignin at different time period before and after inoculation of spot blotch pathogen

\begin{tabular}{|c|c|c|c|c|c|c|c|c|c|c|c|c|}
\hline & \multicolumn{4}{|c|}{$\mathrm{H}_{2} \mathrm{O}_{2}$} & \multicolumn{4}{|c|}{$\mathrm{OH}^{-}$} & \multicolumn{4}{|c|}{$\mathrm{O}_{2}^{-}$} \\
\hline & 0 DAI & $3 \mathrm{DAI}$ & $7 \mathrm{DAI}$ & 14 DAI & 0 DAI & $3 \mathrm{DAI}$ & $7 \mathrm{DAI}$ & $14 \mathrm{DAI}$ & $0 \mathrm{DAI}$ & $3 \mathrm{DAI}$ & 7 DAI & $14 \mathrm{DAI}$ \\
\hline $\mathrm{OH}^{-}$ & 0.058 & -0.007 & $-0.43^{* * *}$ & $-0.27^{* *}$ & & & & & & & & \\
\hline $\mathrm{O}_{2}^{-}$ & -0.169 & $-0.34^{* * *}$ & $-0.69^{* * *}$ & $-0.52^{* * *}$ & $-0.26^{* *}$ & $0.24^{* *}$ & $0.58^{* * *}$ & $0.62^{* * *}$ & & & & \\
\hline Lignin & 0.096 & $0.46^{* * *}$ & $0.32^{* * *}$ & 0.05 & 0.12 & -0.22 & $-0.53^{* * *}$ & $-0.27^{* *}$ & -0.024 & $-0.34^{* * *}$ & $-0.42^{* * *}$ & $-0.39^{* * *}$ \\
\hline
\end{tabular}

$* * *=$ Significant at $P<0.0001, * *=P<0.001 \mathrm{H}_{2} \mathrm{O}_{2}=$ hydrogen peroxide, $\mathrm{OH}^{-}=$hydroxyl ion, $\mathrm{O}_{2}^{-}=$superoxide ions, DAI $=$Days After Inoculation

Fig. 5B and C. There was no significant difference in lignin deposition between susceptible and resistant genotypes at 0 DAI, but after infection lignin deposition increased rapidly in resistant genotypes. Susceptible genotypes also showed less lignification around penetration points, whereas higher lignification around the penetration points, restricting the pathogen, was observed in remaining genotypes. Coalescing lesions appeared in susceptible genotypes, while restricted spots were observed in resistant ones.

Correlation among the free radicals and lignin associated with resistance and susceptibility to $B$. sorokiniana. Estimates of the correlation coefficients among the three free radicals $\left(\mathrm{O}_{2}^{-}, \mathrm{OH}^{-}\right.$, and $\left.\mathrm{H}_{2} \mathrm{O}_{2}\right)$ and lignin at different time points are shown in Table 4. No significant correlation between free radicals and lignin was observed before inoculation (0 DAI) except for $\mathrm{OH}^{-}$which was significantly and negatively correlated with $\mathrm{O}_{2}^{-}$in three measurements (3 DAI, 7 DAI, and 14 DAI). There was a significant positive correlation between $\mathrm{O}^{-}$and $\mathrm{O}_{2}^{-}$. Likewise, $\mathrm{OH}^{-}$ was significantly and negatively correlated with $\mathrm{H}_{2} \mathrm{O}_{2}$ and lignin at 7 DAI and 14 DAI. On the other hand, $\mathrm{H}_{2} \mathrm{O}_{2}$ was significantly and positively correlated with lignin at 3DAI and 7 DAI but negatively with $\mathrm{OH}^{--}$at 7DAI and $14 \mathrm{DAI}$ and with $\mathrm{O}_{2}^{-}$at 3DAI, 7DAI, and 14 DAI. Likewise, $\mathrm{O}_{2}^{-}$ was significantly and negatively correlated with lignin at 3 , 7 and 14 DAI.

Results of the variable cluster analysis indicate the positive regulation of hydrogen peroxide on lignin content, clustering them together (Fig. 3B), whereas the hydroxyl and superoxide radicals appear in a different cluster, that explains maximum of variation (Supplementary Table 3 and 4). From this clustering, it is evident that hydrogen peroxide level is positively correlated with lignin formation but not with superoxide or hydroxyl radicals.

\section{Discussion}

We observed that susceptible genotypes showed lower expression of $\mathrm{H}_{2} \mathrm{O}_{2}$ ROS, resulting in lower lignification at the site of infection, probably leading to higher expressions of lesion area, AUDPC and the number of spores $\mathrm{cm}^{-2}$ lesion but lower lesion numbers and shorter latent periods. These also associated with the variable growth and development of the pathogen (Yusuf et al., 2016). Fast pathogen growth and reproduction accelerated its spread, fostering quick coverage of green area, with significantly reduced biomass and grain yield.

On the contrary, resistant lines recorded higher $\mathrm{H}_{2} \mathrm{O}_{2}$ activity and lignification at penetration and colonization sites, restricting individual lesions and with no or delayed coalesce, resulting in low AUDPCs and more extended latent periods. The pathogen reproduces only after attaining the critical biomass, which is possible only after colonization of sizable amounts of tissue. Higher lignin production at the site of colonization of host tissue interferes with pathogen development, keeping it below critical levels, so most small lesions had no spores, in our study. Lignificationbased protection resulted in higher biomass and grain yield, as the AUDPC directly depends on the spread of disease in leaves (Bashyal et al., 2011), reducing green leaf area and grain filling (Bingham et al., 2009).

The rapid development of disease in a crop largely depends on the amount of secondary inoculum that often appears with a short latent period and increased infection efficiency in the pathogen (Tomerlin et al., 1983). Milus and Line (1980) established a negative correlation of latent period with uredia $/ \mathrm{cm}^{2}$ of the leaf surface, for Puccinia recondita in wheat. We found similar results, wherein genotypes with a shorter latent period showed a larger lesion area, a higher number of spores/lesion, and higher AUDPC. These components were retarded in resistant genotypes. Thus, these traits can be considered predictors of resistance. However, there was no significant difference for incubation period between susceptible and resistant genotypes, indicating that resistance is expressed at the post penetration stage of the pathogen.

Relative resistance is another component of resistance, represented by the efficiencies of monocyclic infections in host-plant genotypes with respect to susceptible controls. 
Quantitative resistance involves many important phenotypic and biochemical factors, including lignification in wheat - B. sorokiniana interactions, which play vital roles in the elucidation of defense responses (Joshi et al., 2004; Sharma et al., 2018). The relative rate of resistance predicts the efficiency of a genotype to sustain the polycyclic form of the disease. For air-dispersed fungi, components of disease such as infection efficiency, latent period, sporulation intensity, lesion expansion, and infectious period has highest impact on epidemics and may be considered as a priority in phenotyping for resistant genotypes. We observed that resistant genotypes significantly reduce the sporulation fitness index, latent period and AUDPC, indicating their ability to sustain grain production under infections involving multiple reproductive cycles of the pathogen.

Lignification as a defence response was seen to be three times greater in resistant wheat genotypes than in susceptible ones, under Karnal bunt infections (Purwar et al., 2012). Eisa et al. (2013) observed a similar role for higher lignification as a barrier to penetration, in spot blotch resistant lines. The concentration of lignin in this study reduced disease expression, resulting in smaller, restricted, nonsporulating lesions, in resistant genotypes. These visual quantitative traits will help wheat breeders to select for resistance in the field experiments.

Significant variation in lignin content among resistant genotypes and its production at the site of infection in our study indicates the scope for selection for higher lignin content in advanced breeding lines. The biosynthesis of lignin begins with the formation of glycosylated monolignols from the L-phenylalanine through general phenylpropanoid and monolignol-specific pathways (Boerjan et al., 2003). Whereas, L-Phenylalanine is derived from the shikimate biosynthetic pathway in the plastid (Dixon et al., 2001) and needs various signals to induce lignification. Among the signaling molecules ROS is reported (Denness et al., 2011). In this study there was no significant difference in $\mathrm{O}_{2}^{-}, \mathrm{OH}^{-}$, and $\mathrm{H}_{2} \mathrm{O}_{2}$ before inoculation in resistant and susceptible genotypes, indicating a balanced production, utilization, and scavenging of ROS, under unstressed conditions. After inoculation with $B$. sorokiniana, $\mathrm{O}_{2}^{-}$and $\mathrm{OH}^{-}$ levels increased gradually in susceptible genotypes but not resistant ones, in which it eventually started decreasing as the genotypes appeared to balance the oxidative stress by the production of antioxidants such as superoxide dismutase and catalases involved in scavenging free radicals (Lightfoot et al., 2017). This finding supports the idea that resistant genotypes are more successful at detoxifying $\mathrm{O}_{2}^{-}$ into less harmful substances such as $\mathrm{H}_{2} \mathrm{O}_{2}$, as part of the resistance response. The increasing ROS in both susceptible and resistant genotypes at 14 DAI might reflect senescence leading to an oxidative burst that produces the superoxide radical and hydrogen peroxide and results in accumulation of the hydroxyl radical (Apel and Hirt, 2004; Hakmaoui et al., 2012).

The role of $\mathrm{H}_{2} \mathrm{O}_{2}$ in wheat defense against Septoria tritici infection has been demonstrated by infection being accompanied by a massive and early $\mathrm{H}_{2} \mathrm{O}_{2}$ accumulation during incompatible interactions, which did not occur during compatible interactions, where there was very little $\mathrm{H}_{2} \mathrm{O}_{2}$ accumulation and hyphae were able to grow in the host apoplast after stomatal penetration. Our results also showed a positive correlation between $\mathrm{H}_{2} \mathrm{O}_{2}$ production and lignin content after inoculation. In resistant genotypes, the amount of lignin and $\mathrm{H}_{2} \mathrm{O}_{2}$ production was higher while the opposite happened in the susceptible. In transgenic potato $\mathrm{H}_{2} \mathrm{O}_{2}$, mediated lignification of the cell wall enhanced disease resistance ( $\mathrm{Wu}$ et al., 1997). The higher $\mathrm{H}_{2} \mathrm{O}_{2}$ produced in resistant genotypes might have been used to synthesize the lignin polymer, with a small amount remaining available to repair cell damage. $\mathrm{H}_{2} \mathrm{O}_{2}$ has been shown to be necessary for the polymerization of cinnamyl alcohols, an essential enzyme in lignin biosynthesis (Ros Barceló, 2005). Virulence in the hemibiotrophic pathogen is directly correlated to $\mathrm{H}_{2} \mathrm{O}_{2}$ production and other ROS and evidenced in Colletotrichum gloeosporioides, Magnaporthe oryzae and Botrytis cinerea where positive correlations occur between sensitivity to $\mathrm{H}_{2} \mathrm{O}_{2}$, peroxidase activity, and fungal pathogenicity and virulence are affected as components of ROS-producing enzymes are lacking. Apart from this, regulation of infection pegs and appressoria regulated by massive accumulation of $\mathrm{H}_{2} \mathrm{O}_{2}$ and $\mathrm{O}_{2}^{-}$is also evidenced by Marschall and Tudzynski (2016). The local generation of $\mathrm{H}_{2} \mathrm{O}_{2}$ is closely associated with effective penetration resistance (Schäfer et al., 2004; Shetty et al., 2007) since $\mathrm{H}_{2} \mathrm{O}_{2}$ produces necrosis in cells around the pathogen to localize its attack and acts to prevent the fungal penetration to epidermal cells (Kumar et al., 2002; Mellersh et al., 2002) and was evident in present study also. Recently, Sharma et al. (2018) has demonstrated that $\mathrm{H}_{2} \mathrm{O}_{2}$ is one of the vital defense signaling molecules that trigger resistance to $B$. sorokiniana in wheat. The differential clustering of the genotypes based on phenotyping, free radical production and lignin accumulation in response to B. sorokiniana infection suggested the role of these factors in resistance to spot blotch in wheat. This was confirmed by histochemical staining, which provided insights concerning the restriction of the pathogen at penetration sites. This study hence makes it easy to understand the role of $\mathrm{H}_{2} \mathrm{O}_{2}$ and lignin in resistance to $B$. sorokiniana and suggests host plant lignin 
content as a possible biochemical marker for spot blotch resistance in wheat.

\section{Acknowledgments}

Authors are thankful to CRP-WHEAT Partnership Grants for financial support. Sudhir Navathe is grateful to DST, Govt. of India for the INSPIRE fellowship (IF150037).

\section{References}

Aldaeus, F. 2011. Protocol for round robin test of lignin content in lignin samples COST FP0901. URL http://web.abo.fi/fak/ tkf/spk/costfp0901/Round_robin/COST_FP0901-Protocol_ for_round_robin_test_of_lignin_content-version_3.pdf $[\overline{6}$ July 2019].

Apel, K. and Hirt, H. 2004. Reactive oxygen species: metabolism, oxidative stress, and signal transduction. Annu. Rev. Plant Biol. 55:373-399.

Bashyal, B. M., Chand, R., Prasad, L. C. and Joshi, A. K. 2011. Partial resistance components for the management of spot blotch pathogen Bipolaris sorokiniana of barley (Hordeum vulgare L.) Acta Phytopathol. Entomol. Hung. 46:49-57.

Beardmore, J., Ride, J. P. and Granger, J. W. 1983. Cellular lignification as a factor in the hypersensitive resistance of wheat to stem rust. Physiol. Plant Pathol. 22:209-220.

Bhuiyan, N. H., Selvaraj, G., Wei, Y. and King, J. 2009. Role of lignification in plant defense. Plant Signal Behav. 4:158-159.

Bingham, I. J., Walters, D. R., Foulkes, M. J. and Paveley, N. D. 2009. Crop traits and the tolerance of wheat and barley to foliar disease. Ann. Appl. Biol. 154:159-173.

Bird, P. M. and Ride, J. P. 1981. The resistance of wheat to Septoria nodorum: fungal development in relation to host lignification. Physiol. Plant Pathol. 19:289-299.

Bishop, D. L., Chatterton, N. J., Harrison, P. A. and Hatfield, R. D. 2002. Changes in carbohydrate coordinated partitioning and cell wall remodeling with stress-induced pathogenesis in wheat sheaths. Physiol. Mol. Plant Pathol. 61:53-63.

Boerjan, W., Ralph, J. and Baucher, M. 2003. Lignin biosynthesis. Annu. Rev. Plant Biol. 54:519-546.

Boudet, A. M. 2000. Lignins and lignification: selected issues. Plant Physiol. Biochem. 38:81-96.

Caño-Delgado, A., Penfield, S., Smith, C., Catley, M. and Bevan, M. 2003. Reduced cellulose synthesis invokes lignification and defense responses in Arabidopsis thaliana. Plant J. 34:351-362.

Chand, R., Yadav, O. P., Bashyal, B. M., Prasad, L. C. and Joshi, A. K. 2013. Technique for the maintenance of heterokaryotic isolates of B. sorokiniana. Indian Phytopathol. 66:61-65.

Das, M. K., Rajaram, S., Kronstad, W. E., Mundt, C. C. and Singh, R. P. 1993. Associations and genetics of three components of slow rusting in leaf rust of wheat. Euphytica 68:99109.
Denness, L., McKenna, J. F., Segonzac, C., Wormit, A., Madhou, P., Bennett, M., Mansfield, J., Zipfel, C. and Hamann, T. 2011. Cell wall damage-induced lignin biosynthesis is regulated by a reactive oxygen species-and jasmonic aciddependent process in Arabidopsis. Plant Physiol. 156:13641374.

Dixon, R. A., Chen, F., Guo, D. and Parvathi, K. 2001. The biosynthesis of monolignols: A "metabolic grid", or independent pathways to guaiacyl and syringyl units? Phytochemistry 57:1069-1084.

Dubin, H. J. and van Ginkel, M. 1991. The status of wheat diseases and disease research in warmer areas. In: Wheat for the nontraditional warm areas: A proceedings of the International Conference, ed. by D. A. Saunders, pp. 125-145. International Maize and Wheat Improvement Center, Mexico City, Mexico.

Eisa, M., Chand, R. and Joshi, A. K. 2013. Biochemical and histochemical traits: a promising way to screen resistance against spot blotch Bipolaris sorokiniana of wheat. Eur. J. Plant Pathol. 137:805-820.

Elad, Y. and Evensen, K. 1995. Physiological aspects of resistance to Botrytis cinerea. Phytopathology 85:637-643.

Gupta, P. K., Chand, R., Vasistha, N. K., Pandey, S. P., Kumar, U., Mishra, V. K. and Joshi, A. K. 2018. Spot blotch disease of wheat: the current status of research on genetics and breeding. Plant Pathol. 67:508-531.

Gurung, S., Mahto, B. N., Gyawali, S. and Adhikari, T. B. 2013. Phenotypic and molecular diversity of Cochliobolus sativus populations from wheat. Plant Dis. 97:62-73.

Hakmaoui, A., Pérez-Bueno, M. L., García-Fontana, B., Camejo, D., Jiménez, A., Sevilla, F. and Barón, M. 2012. Analysis of the antioxidant response of Nicotiana benthamiana to infection with two strains of Pepper mild mottle virus. J. Exp. Bot. 63:5487-5496.

Halliwell, B., Gutteridge, J. M. and Aruoma, O. I. 1987. The deoxyribose method: a simple "test-tube" assay for determination of rate constants for reactions of hydroxyl radicals. Anal. Biochem. 165:215-219.

Jacobo-Velázquez, D. A., González-Agüero, M. and CisnerosZevallos, L. 2015. Cross-talk between signaling pathways: the link between plant secondary metabolite production and wounding stress response. Sci. Rep. 5:8608.

Joshi, A. K. and Chand, R. 2002. Variation and inheritance of leaf angle, and its association with spot blotch Bipolaris sorokiniana severity in wheat Triticum aestivum. Euphytica 124:283291.

Joshi, A. K., Chand, R. and Arun, B. 2002. Relationship of plant height and days to maturity with resistance to spot blotch in wheat. Euphytica 123:221-228.

Joshi, A. K., Kumar, S., Chand, R. and Ortiz-Ferrara, G. 2004. Inheritance of resistance to spot blotch caused by Bipolaris sorokiniana in spring wheat. Plant Breed. 123:213-219.

Kumar, J., Schäfer, P., Hückelhoven, R., Langen, G., Baltruschat, H., Stein, E., Nagarajan, S. and Kogel, K.-H. 2002. Bipolaris 
sorokiniana, a cereal pathogen of global concern: cytological and molecular approaches towards better control. Mol. Plant Pathol. 3:185-195.

Levene, H. 1960. Robust tests for equality of variances. In: Contributions to probability and statistics, ed. by I. Olkin, pp. 278-292. Stanford University Press, Palo Alto, CA, USA.

Lightfoot, D. J., McGrann, G. R. and Able, A. J. 2017. The role of a cytosolic superoxide dismutase in barley-pathogen interactions. Mol. Plant Pathol. 18:323-335.

Marschall, R. and Tudzynski, P. 2016. Reactive oxygen species in development and infection processes. Semin. Cell Dev. Biol. 57:138-146.

Mehta, Y. R. 1998. Constraints on the integrated management of spot blotch of wheat. In: Helminthosporium blights of wheat: Spot blotch and tan spot, eds. by E. Duveiller, H. J. Dubin, J. Reeves and A. McNab, pp. 18-27. International Maize and Wheat Improvement Center, Mexico City, Mexico.

Mellersh, D. G., Foulds, I. V., Higgins, V. J. and Heath, M. C. 2002. $\mathrm{H}_{2} \mathrm{O}_{2}$ plays different roles in determining penetration failure in three diverse plant-fungal interactions. Plant J. 29:257-268.

Miedes, E., Vanholme, R., Boerjan, W. and Molina, A. 2014. The role of the secondary cell wall in plant resistance to pathogens. Front. Plant Sci. 5:358.

Milus, E. A. and Line, R. F. 1980. Characterization of resistance to leaf rust in Pacific Northwest wheats. Phytopathology 70:167-172.

Misra, H. P. and Fridovich, I. 1972. The role of superoxide anion in the autoxidation of epinephrine and a simple assay for superoxide dismutase. J. Biol. Chem. 247:3170-3175.

Nicholson, R. L. and Hammerschmidt, R. 1992. Phenolic compounds and their role in disease resistance. Annu. Rev. Phytopathol. 30:369-389.

Parlevliet, J. E. 1979. Components of resistance that reduce the rate of epidemic development. Annu. Rev. Phytopathol. 17:203-222.

Patterson, B. D., MacRae, E. A. and Ferguson, I. B. 1984. Estimation of hydrogen peroxide in plant extracts using titanium IV. Anal. Biochem. 139:487-492.

Purwar, S., Gupta, S. M. and Kumar, A. 2012. Enzymes of phenylpropanoid metabolism involved in strengthening the structural barrier for providing genotype and stage-dependent resistance to Karnal bunt in wheat. Am. J. Plant Sci. 3:261267.

Ros Barceló, A. 2005. Xylem parenchyma cells deliver the $\mathrm{H}_{2} \mathrm{O}_{2}$ necessary for lignification in differentiating xylem vessels. Planta 220:747-756.

Schäfer, P., Hückelhoven, R. and Kogel, K. H. 2004. The white barley mutant albostrians shows a super-susceptible but symptomless interaction phenotype with the hemibiotrophic fungus Bipolaris sorokiniana. Mol. Plant-Microbe Interact. 17:366-373.

Shaner, G. and Finney, R. E. 1977. The effect of nitrogen fertil- ization on the expression of slow-mildewing in Knox wheat. Phytopathology 67:1051-1056.

Shapiro, S. S. and Wilk, M. B. 1965. An analysis of variance test for normality (complete samples). Biometrika 52:591-611.

Sharma, S., Sahu, R., Navathe, S., Mishra, V. K., Chand, R., Singh, P. K., Joshi, A. K. and Pandey, S. P. 2018. Natural variation in elicitation of defense-signaling associates to field resistance against the spot blotch disease in bread wheat (Triticum aestivum L.). Front. Plant Sci. 9:636.

Shetty, N. P., Mehrabi, R., Lütken, H., Haldrup, A., Kema, G. H., Collinge, D. B. and Jørgensen, H. J. 2007. Role of hydrogen peroxide during the interaction between the hemibiotrophic fungal pathogen Septoria tritici and wheat. New Phytol. 174:637-647.

Sillero, J. C. and Rubiales, D. 2002. Histological characterization of resistance to Uromyces viciae-fabae in faba bean. Phytopathology 92:294-299.

Singh, P. K., Zhang, Y., He, X., Singh, R. P., Chand, R., Mishra, V. K., Malaker, P. K., Reza, M. A., Rahman, M. M., Islam, R., Chowdhury, A. K., Bhattacharya, P. M., Kalappanavar, I. K., Crossa, J. and Joshi, A. K. 2015. Development and characterization of the 4th CSISA-spot blotch nursery of bread wheat. Eur. J. Plant Pathol. 143:595-605.

Southerton, S. G. and Deverall, B. J. 1990. Histochemical and chemical evidence for lignin accumulation during the expression of resistance to leaf rust fungi in wheat. Physiol. Mol. Plant Pathol. 36:483-494.

Thordal-Christensen, H., Zhang, Z., Wei, Y. and Collinge, D. B. 1997. Subcellular localization of $\mathrm{H}_{2} \mathrm{O}_{2}$ in plants. $\mathrm{H}_{2} \mathrm{O}_{2}$ accumulation in papillae and hypersensitive response during the barley-powdery mildew interaction. Plant J. 11:1187-1194.

Tomerlin, J. R., Eversmeyer, M. G., Kramer, C. L. and Browder, L. E. 1983. Temperature and host effects on latent and infectious periods and urediniospore production of Puccinia recondita $\mathrm{f}$. sp. tritici. Phytopathology 73:414-419.

Tronchet, M., Balagué, C., Kroj, T., Jouanin, L. and Roby, D. 2010. Cinnamyl alcohol dehydrogenases-C and D, key enzymes in lignin biosynthesis, play an essential role in disease resistance in Arabidopsis. Mol. Plant Pathol. 11:83-92.

Willocquet, L., Savary, S. and Yuen, J. 2017. Multiscale phenotyping and decision strategies in breeding for resistance. Trends Plant Sci. 22:420-432.

Wu, G., Shortt, B. J., Lawrence, E. B., Leon, J., Fitzsimmons, K. C., Levine, E. B., Raskin, I. and Shah, D. M. 1997. Activation of host defense mechanisms by elevated production of $\mathrm{H}_{2} \mathrm{O}_{2}$ in transgenic plants. Plant Physiol. 115:427-435.

Yusuf, C. S., Chand, R., Mishra, V. K. and Joshi, A. K. 2016. The association between leaf malondialdehyde and lignin content and resistance to spot blotch in wheat. J. Phytopathol. 164:896-903.

Zadoks, J. C., Chang, T. T. and Konzak, C. F. 1974. A decimal code for the growth stages of cereals. Weed Res. 14:415-421. 